\title{
Bird-habitat associations in coastal rangelands of southern Brazil
}

\author{
Rafael A. Dias ${ }^{1,2}$, Vinicius A. G. Bastazini ${ }^{1,3} \&$ Andros T. Gianuca ${ }^{1,4}$
}

1. Laboratório de Ecologia e Conservação, Universidade Católica de Pelotas, Rua Félix da Cunha, 412, 96010-000, Pelotas, RS, Brazil. (rafael.dias@ufpel.edu.br)

2. Current address: Departamento de Ecologia, Zoologia e Genética, Instituto de Biologia, Universidade Federal de Pelotas, Campus Universitário Capão do Leão, Caixa Postal 354 , 96010-900, Pelotas, RS, Brazil.

3. Current address: Programa de Pós-Graduação em Ecologia, Instituto de Biociências, Universidade Federal do Rio Grande do Sul, Av. Bento Gonçalves 9500, 91501-970,

Porto Alegre, RS, Brazil.

4. Current address: Laboratory of Aquatic Ecology, Evolution and Conservation, University of Leuven, Ch Deberiotstraat 32, 3000, Leuven, Belgium.

\begin{abstract}
Nearly all remnants of temperate grasslands in southeastern South America are used for livestock ranching and are subject to habitat degradation resulting from this activity. Exploring how habitat features affect the composition of grassland avifaunal communities is a first step to understand how current cattle-ranching management practices impact avian diversity. We used canonical ordination to test for relationships between five habitat variables and the composition of the bird community in coastal grasslands in southern Brazil. We sampled pastures with different heights, from overgrazed short-grass to tall herbaceous vegetation. We recorded 1,535 individuals and 27 species of birds. The first ordination axis indicated a strong contribution of mean vegetation height on the composition of the bird community, whereas the second axis revealed the influence of herbaceous vegetation patchiness and woody vegetation cover. Three groups of species were revealed by the ordination: one more diffuse associated with intermediate and tall herbaceous vegetation, another with short grass, and a third with vegetation patchiness and woody vegetation. Species restricted to tall herbaceous vegetation are negatively impacted from habitat degradation resulting from overgrazing and trampling by livestock, and mowing and burning of tall plants. Occurrence of these species in our study area is related with the presence of swales immediately behind the dune system and where remnants of tall vegetation persist. Birds of pastures with ample cover of short herbaceous plants, including one globally threatened species and six other restricted to short-grass habitat, apparently benefit from local livestock management practices. Woody vegetation possibly functions as a keystone structure, enabling the occurrence in grasslands of avian species that rely on shrubby habitat. Although livestock ranching promotes the diversity of habitats by creating distinct patches of vegetation height in grasslands, current management practices directed to the maintenance of short grass pastures may eliminate an entire subset of species, including regionally threatened taxa, and reduce avian diversity. The maintenance of large patches of tall herbaceous plants is needed to ensure the survival of species reliant on this type of grassland structure in our study area.
\end{abstract}

KEYWORDS. Habitat use, livestock ranching, grassland management, canonical ordination, “Campos” grasslands.

RESUMO. Associações entre aves e variáveis de habitat em campos costeiros do sul do Brasil. Praticamente todos os remanescentes de campo temperado no sudeste da América do Sul são usados para a pecuária e estão sujeitos à degradação de habitat resultante dessa atividade. Explorar como a composição das comunidades de aves é influenciada por características de habitat é um passo inicial para compreender o impacto que as atuais práticas de manejo da pecuária em campos nativos exercem sobre a biodiversidade. Nós usamos ordenação canônica para testar as relações entre cinco variáveis de habitat e a composição da comunidade de aves em campos costeiros do sul do Brasil. Amostramos pastagens nativas de diferentes alturas, variando de campos sobrepastejados até aqueles cobertos por vegetação herbácea de porte elevado. Registramos 1.535 indivíduos e 27 espécies de aves. O primeiro eixo de ordenação indicou uma forte contribuição de altura média da vegetação sobre a composição da comunidade de aves, enquanto o segundo eixo demonstrou a influência da variação vertical da altura da vegetação herbácea e da cobertura de vegetação lenhosa. Três grupos de espécies foram revelados pela ordenação: um mais difuso associado com vegetação herbácea de porte intermediário e alto, outro com vegetação baixa, e um terceiro relacionado com a variação vertical da altura da vegetação herbácea e a cobertura de vegetação lenhosa. Espécies restritas à vegetação herbácea de porte alto são impactadas negativamente pela degradação do habitat resultante do sobrepastejo e pisoteio, além de roçadas e queimadas. A ocorrência dessas aves em nossa área de estudo está relacionada à presença de depressões situadas imediatamente atrás do sistema de dunas e onde os remanescentes de vegetação alta persistem. Aves de pastagens com ampla cobertura de plantas herbáceas de porte baixo, incluindo uma espécie globalmente ameaçada e outras seis restritas a esse tipo de habitat, aparentemente se beneficiam das práticas locais de pecuária. A vegetação lenhosa possivelmente atua como uma estrutura-chave em campos, favorecendo a ocorrência de espécies que dependem de habitats arbustivos. Embora a pecuária promova a diversidade de habitats em campos ao criar um mosaico de manchas de vegetação de alturas variáveis, as atuais práticas de manejo voltadas para a manutenção de pastagens de gramíneas baixas podem eliminar um subconjunto inteiro de espécies, incluindo táxons regionalmente ameaçados, e reduzir a diversidade de aves em campos. A manutenção de grandes manchas de plantas herbáceas de porte alto é necessária para garantir a sobrevivência de espécies dependentes deste tipo de vegetação em nossa área de estudo.

PALAVRAS-CHAVE. Uso de habitat, pecuária, manejo de campos, ordenação canônica, Campos.

Habitat loss and degradation has been particularly severe in temperate grasslands, with grassland birds experiencing expressive populational declines in recent decades (VICKERY \& HERKERT, 2001; FISHER \& DAVIS, 2010). Expansion of agriculture, afforestation and urbanization are the main causes of habitat loss, whereas overgrazing and trampling by livestock and inadequate burning regimes are the main drivers of habitat degradation (HENWOOD, 2010; AzPIROz et al., 2012).
The plight of grassland birds has spawned a series of investigations addressing grassland-bird habitat relationships (see FisHER \& DAVIS, 2010). One of the main conclusions of these studies is that the abundance and distribution of species, and the composition of avian communities in grasslands, are largely determined by variations in specific habitat features (VICKERY \& HERKERT, 2001; Derner et al., 2009; Fisher \& Davis, 2010; AzPIROZ et al., 2012). The heterogeneity of the vegetation and 
the presence of "keystone structures" - distinct spatial structures that provide resources, shelter, or goods and services crucial for other species - are the main habitat features that influence the diversity and composition of avifaunal communities in grasslands (Tews et al., 2004; FISHER \& DAVIS, 2010). These variables are mediated by complex interactions between "ecosystem engineers" such as grazers and burrowers, and fire and drought regimes (Ceballos et al., 1999; Fuhlendorf et al., 2009; Allred et al., 2011).

Most studies focusing on grassland-bird habitat relationships have been conducted in North America and Europe (FISHER \& DAVIS, 2010; BÁLDI \& BATÁRY, 2011). In southeastern South America, where temperate grasslands once covered 762,000 $\mathrm{km}^{2}$ in southern Paraguay and Brazil, Uruguay, and eastern Argentina, the majority of studies addressing this issue have been conducted in the Argentine Pampas unit (AzPiroz et al., 2012). These studies have shown that variations in grazing and burning intensity affect the height and density of the herbaceous vegetation, thus determining the occurrence of bird communities associated with tall-grass, short-grass and a mosaic of tall and short vegetation, as well as a series of generalist species capable of using a broader spectrum of vegetation types (Comparatore et al., 1996; Isacch \& Martínez, 2001, 2003; IsACCH \& CARDONI, 2011; IsACCH et al., 2005). Less is known about patterns of habitat use by birds in the Campos unit of northeastern Argentina, Uruguay, and southern Brazil, where the largest grassland remnants are located (AzPIROz et al., 2012). A study in Uruguay demonstrated that natural grasslands were important for grassland specialists, including threatened species, when compared to modified pastures and agricultural habitats (Azpiroz \& Blake, 2009). In southern Brazil, Gressler (2008) showed that species richness was higher in the largest grassland remnant, which also harbored threatened and data deficient grassland taxa.

Lack of knowledge on relationships between habitat features and bird communities in the Campos unit is troublesome for two reasons. First, only $40-45 \%$ of the original Campos grasslands remain and what is left is being converted into soybean and tree plantations (Henwood, 2010; AzPIROz et al., 2012). Second, because most of the remaining grasslands are used for livestock ranching, remnants of natural vegetation are subject to habitat degradation resulting from grazing and trampling (AzPIROZ et al., 2012). Considering that only $1 \%$ of the Campos grasslands are protected in reserves, conservation of grassland biodiversity depends largely on the development of sound livestock management techniques implemented on private rangelands (Develey et al., 2008; Azpiroz et al., 2012).

Habitat identification, management and restoration, and knowledge of grassland-bird habitat use and selection, are key aspects to stabilize or increase grassland bird populations (FISHER \& DAVIS, 2010). Thus, exploring the influence of habitat features on the composition of bird communities in the Campos grasslands of southern Brazil is a first step towards a better understanding of how habitat variables affect groups of species in a similar way. This is particularly important because grassland birds respond to local habitat structure, and responses may vary throughout a species range (Wiens, 1969; Azpiroz et al., 2012). Consequently, regional management and conservation of grassland bird habitat relies on knowledge generated across multiple local scales. Results from such a study would enable managers and conservationists to discern groups of species which are being positively or negatively affected by land-use practices, and ensure the prioritization of habitat features for management. Knowledge of the necessary habitat heterogeneity required to ensure the coexistence of multiple species is also important for the maintenance of diversity in grassland bird communities.

Our objective was to explore how habitat features affect the composition of the avian community in temperate coastal grasslands of southern Brazil. We used canonical ordination to test how vegetation attributes and structural features of grasslands influence the abundance and composition of the bird community, seeking for relationships between species and environmental descriptors of grasslands. We determined which habitat features are most important in determining habitat use by grassland birds, and defined groups of species that respond similarly to variations in these features.

\section{MATERIAL AND METHODS}

Study area. We worked in coastal grasslands of southern Brazil around Cassino seaside resort $\left(32^{\circ} 11^{\prime} \mathrm{S}\right.$, $52^{\circ} 10^{\prime} \mathrm{W}$ ), state of Rio Grande do Sul. Grasslands lay immediately behind coastal dunes and cover sandy soils exhibiting a complex system of shallow depressions. Deeper swales covered with wetland vegetation cross the area.

Livestock grazing is currently the most important driver of vegetation structure in our study area. Adjusting the number of livestock in pastures is the main management practice, with mowing and burning used occasionally where tall and dense vegetation occurs. Pastures usually have two strata: short vegetation $1-20 \mathrm{~cm}$ tall and a taller layer of unpalatable tussocks and forbs up to 70 $\mathrm{cm}$ in height. Homogeneous short herbaceous patches are found in a few overgrazed pastures. In some sectors, large remnant patches of homogeneous tall herbaceous vegetation occur. The presence of these tall patches is largely influenced by the micro-relief, since they tend to be located in shallow depressions that predominate immediately behind the coastal dune system. These areas are marginal in relation to other pastures in ranches, are difficult to mow, and livestock grazing is minimal due to unpalatability or low forage quality of tall herbaceous plants. Some ranchers occasionally set fire to these patches to open up the vegetation, but burning is limited due to restrictions imposed by the Brazilian environmental law and overall dampness of the terrain. 
Grasslands in our study area are dominated by Poaceae, with Cyperaceae covering wetter sectors in depressions. Androtrichum trigynum (Cyperaceae) and Juncus acutus (Juncaceae) are the dominant species of the tall stratum. Scattered shrubs, cacti, and small trees occur throughout our study area, as well as small $\left(<10000 \mathrm{~m}^{2}\right)$ eucalyptus stands. The primary livestock in our study area are cattle; horses and Asian water buffalo are also found in some ranches. Ranchers in southern Brazil frequently plant the exotic Lolium (Poaceae) and Trifolium (Fabaceae) as supplemental forage for livestock, a practice that does not occur in our study area.

Climate in the region is humid to sub-humid; mean annual precipitation is $\sim 1200 \mathrm{~mm}$, and mean annual temperature is $18^{\circ} \mathrm{C}$ (IBGE, 1986). Precipitation is slightly higher in the winter and spring, and water deficit can occur in dry summers (IBGE, 1986). Depressions in grasslands are flooded by rains in autumn-winter and most dry out in the summer.

Sampling design. We sampled 21 pastures totaling 1,556 ha of grasslands. We sampled pastures with a range of heights, from overgrazed, homogeneous short-grass pastures to pastures with ample cover of tall herbaceous vegetation. We only sampled pastures large enough to contain at least one sampling plot, maintaining a minimum distance of $200 \mathrm{~m}$ from fences, wetlands, and patches of trees to avoid edge effects (REESE \& RATTI, 1988). Isolated saplings and cacti were included in plots.

We counted birds in 33 plots, each measuring $500 \mathrm{x}$ $120 \mathrm{~m}$. The number of plots in pastures varied from 1 to 4 . In very large pastures we followed a systematic sampling scheme, locating the first plot $200 \mathrm{~m}$ from the borders and placing the others sequentially at $200-\mathrm{m}$ intervals to avoid double-counting birds.

Bird counts. Sampling was carried out between 31 October and 5 November 2008, coinciding with the breeding season of the local resident avifauna, which extends from September to December (Maurício et al., 2013). Because birds are more vocal and restricted to territories during this time of the year, we expected to maximize detection and minimize the probability of doublecounting individuals (BiBBy et al., 1992).

We used a modified version of the area-search method described in RALPH et al. (1993) to count birds. In the original method, one or more observers walk in a haphazard manner for 20 min through three search areas inside a plot of variable size (RALPH et al., 1993). Search areas can have adjoining boundaries or can be in completely separate regions of the plot (RALPH et al., 1993). When counting birds in a plot, the observer is allowed to search for quiet birds and track down unfamiliar vocalizations for visual identification or tape-recording for subsequent identification (RALPH et al., 1993). The area-search method has been used to count birds in grassland habitats, and enhancing detectability of secretive species is one of its main advantages (DIENI \& JONES, 2002; ATKINSON et al., 2006; Roberts \& SCHNell, 2006). Because we were interested in an index of abundance rather than density estimates, area-search enabled us to better locate secretive species in tall vegetation than the time-consuming spotmapping or distance sampling methods.

The modifications to the original method described in RALPH et al. (1993) were twofold: we used two search areas instead of three, and sampled each search area once for 15-20 min instead of $20 \mathrm{~min}$. These modifications enabled two observers (RAD and ATG) to count birds simultaneously in a plot, each being responsible for one search area (i.e., a 500 x $60 \mathrm{~m}$ half-section of the plot). Once a count started, each observer walked along the full length of the search-area, passing within $10 \mathrm{~m}$ of all points inside the perimeter of the search-area (ROBERTS $\&$ SCHNell, 2006). Observers walked at the same pace and communicated frequently via voice to ensure that individual birds were not double-counted. We were able to fully sample plots in overgrazed pastures in 15 minutes, while plots in other pastures were sampled in 20 minutes.

All individuals seen or heard vocalizing were counted. Birds foraging or displaying in flight up to $30 \mathrm{~m}$ above the plot were included, with the exception of martins and swallows, whose small size and agile flight hampered our ability to avoid double-counts between and within plots. Counts were carried out in the first four hours after sunrise on clear days with wind speed $<5$ on the Beaufort scale (BiBBy et al., 1992; McCoy et al., 2001). We used $12 \times 50$ binoculars to help identify birds, and a hand-held GPS unit to delineate plots $( \pm 5 \mathrm{~m})$.

Nomenclature and taxonomic sequence are in accordance with REMSEN et al. (2013). Global threat status follows IUCN (2012), whereas regional threat status follows BENCKE et al. (2003).

Habitat variables. Definitions of variables follow Fisher \& DAVIS (2010). We measured the height of the herbaceous vegetation with a ruler at 5-m intervals along nine linear transects spaced $50 \mathrm{~m}$ apart and oriented perpendicular to the length of plots (or $120 \mathrm{~m}$ in length; $N=216$ measures per plot). We calculated the mean and the coefficient of variation for use in subsequent analyses. The coefficient of variation was used as a measure of patchiness of the herbaceous vegetation (FISHER \& DAVIS, 2010). We visually estimated the proportion of bare ground in each $25 \times 25 \mathrm{~m}$ section of the plot and pooled values to obtain a total estimate. This same procedure was used to determine the cover of standing water and woody vegetation. Woody vegetation included all isolated saplings, shrubs, and clumps of cacti taller than the surrounding herbaceous vegetation.

Data analyses. We built a correlation matrix to check for multicollinearity (LEGENDRE \& LEGENDRE, 1998) in our set of habitat variables. All pairs of variables presented correlation coefficients $<50 \%$ (largest value: 0.48 between patchiness and woody vegetation) and were thus kept in our model.

We used Canonical Correspondence Analysis (CCA) (TER BRAAK, 1986) to explore the relationship between habitat variables and the composition of the bird 
community. CCA is a method of direct gradient analysis, which maximizes the linear relationship between a set of multiple independent variables and another of dependent variables (TER BRAAK, 1986; LEGENDRE \& LEGENDRE, 1998). We evaluated the significance of the first canonical axis and of all canonical axes together using a Monte Carlo method, permutating the model residuals (9999 permutations) under the reduced model (see Lepš \& ŠMilauer, 2003). The null hypothesis assumes no relation between species and habitat variables. Abundance values were square-root transformed. We only analyzed species recorded in three or more plots (incidence $\geq 9 \%$ ). Values of rare species were down-weighted to minimize their influence on the analysis (Lepš \& Šmilauer, 2003). Axes scaling focused on interspecies distance. The CCA was carried out in CANOCO 4.5 statistical software (TER BRAAK \& ŠMilauer, 2002).

\section{RESULTS}

Habitat structure. Mean vegetation height in plots ranged from 5.6-60.4 $\mathrm{cm}($ mean $=23.3$; $\mathrm{SD}=17.9)$, while patchiness of the herbaceous vegetation ranged from $0.5-2.1$ (mean $=1.0 ; \mathrm{SD}=0.5)$. Values of patchiness were lower in plots located in pastures with tall herbaceous vegetation $>40 \mathrm{~cm}$, as well as in overgrazed areas $<10$ $\mathrm{cm}$ in height (Fig. 1).

We recorded patches of bare ground in 18 plots, which covered 5-8010 $\mathrm{m}^{2}$ per plot. Large patches of bare
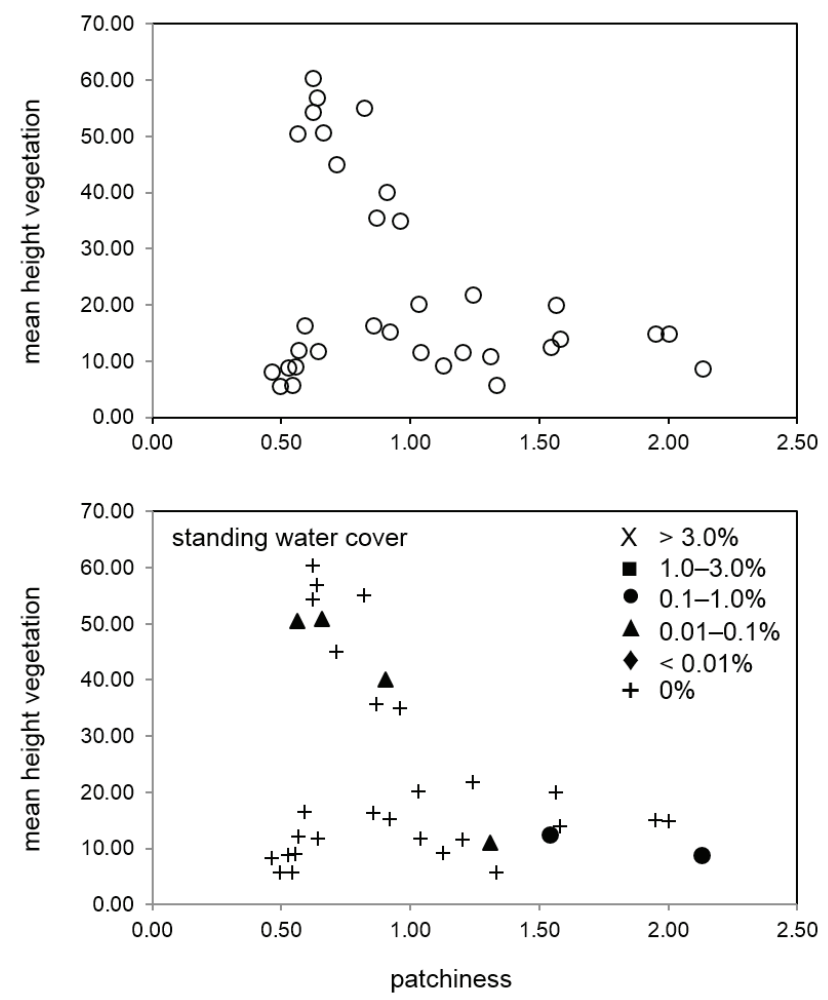

ground were present both in tall and short herbaceous vegetation plots (Fig. 1). Water-filled depressions were found in six plots and ranged in area from 10-200 $\mathrm{m}^{2}$. Larger patches of water were found in short-grass plots with high values of patchiness (Fig. 1). Woody plants were found in eight of 33 plots and ranged from 5-180 $\mathrm{m}^{2}$. Cover of woody plants was larger in plots with intermediate levels of patchiness (Fig. 1).

Bird community. We recorded 1,535 individuals and 27 species of birds with incidence values $\geq 9 \%$ (Tab. I). Vanellus chilensis (Molina, 1782) and Sicalis luteola (Sparrman, 1789) displayed the highest incidence and abundance.

Bird-habitat relationships. The first two canonical axes explained $84.6 \%$ (first axis $=67.6$; second axis $=17.0$ ) of the total explainable variation (Fig. 2). The global test of significance showed that the canonical relationship between both matrices was highly significant (first canonical axis: $F$-ratio $=8.9 ; P=0.0001$; all canonical axes: $F$-ratio $=$ $3.1 ; P=0.0001)$. We found a strong correlation between habitat variables and species composition in the first two axes ( $r=0.96$ and $r=0.87$, respectively). The first axis indicated a strong contribution of mean vegetation height on the composition of the bird community, whereas the second axis was related to patchiness and woody vegetation cover (Fig. 2). Bare ground and water cover had minor contributions to variation in the composition of the bird community.
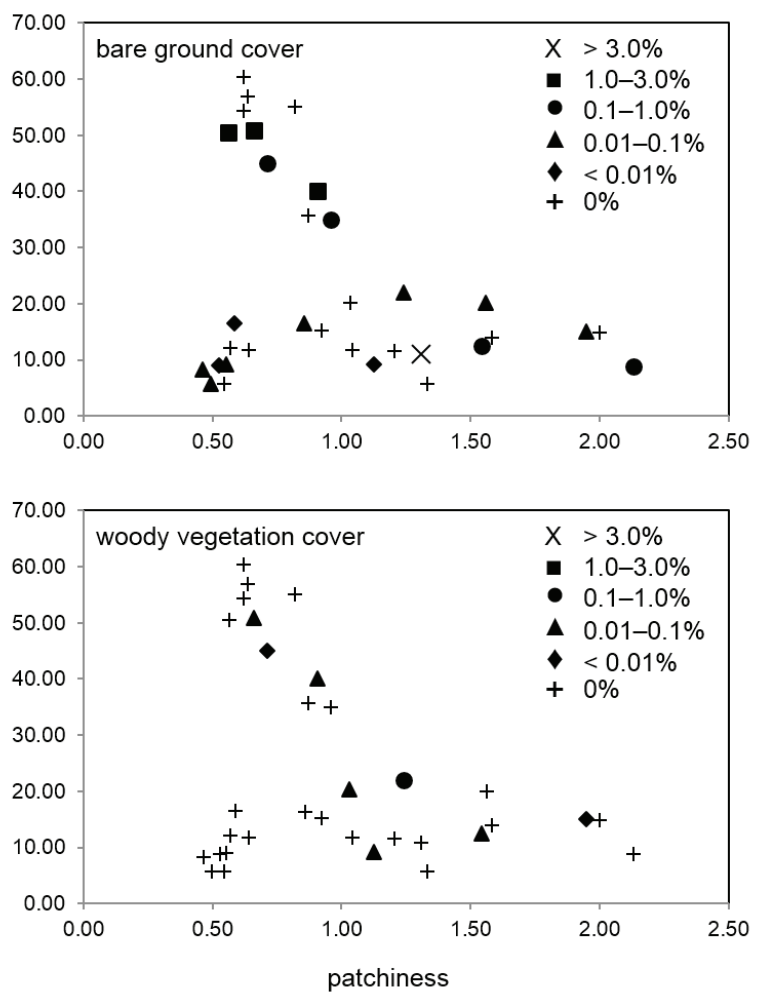

Fig. 1. Summary of habitat variables measured in 33 plots in coastal grasslands of southern Brazil. The upper left panel shows the relationship between the mean height of the herbaceous vegetation $(\mathrm{cm})$ and patchiness of herbaceous vegetation (i.e., the coefficient of variation of the height of the herbaceous vegetation) in plots. The remaining panels show the percentage of cover of bare ground, standing water and herbaceous vegetation in plots in relation to the mean height of the herbaceous vegetation and patchiness. 


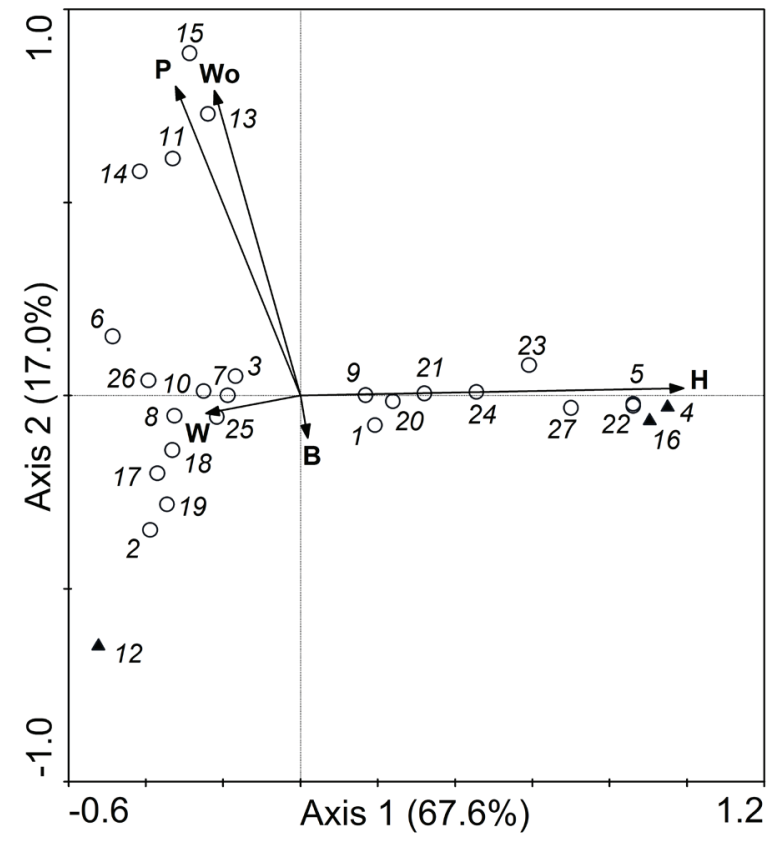

Fig. 2. Canonical Correspondence Analysis (CCA) ordination diagram showing relationships between birds and habitat descriptors in coastal grasslands of southern Brazil. Vectors represent habitat variables highly correlated with both axes. Dark triangles indicate regionally and globally threatened species. (B, bare ground cover; $\mathrm{H}$, mean height of herbaceous vegetation; $\mathrm{P}$, patchiness of herbaceous vegetation; $\mathrm{W}$, water cover; Wo, woody vegetation cover). Numerical codes for species are given in Tab. I.

Three groups of species were revealed by the ordination. The first, more diffuse, is formed by species associated with a gradient of increasing mean vegetation height ranging from 25 to $>50 \mathrm{~cm}$ (Tab. I, Fig. 2). In the ordination, Nothura maculosa (Temminck, 1815), Milvago chimango (Vieillot, 1816), Anthus hellmayri Hartert, 1909 and S. luteola were located closer to the origin of the axes. These three species were more numerous in pastures of intermediate height $(25-30 \mathrm{~cm})$, declining in abundance towards both extremes of the height gradient. Ammodramus humeralis (Bosc, 1792), Embernagra platensis (Gmelin, 1789) and Sturnella superciliaris (Bonaparte, 1850) occurred from the mid to the tall extreme of the height gradient. Cistothorus platensis (Latham, 1790), Emberizoides ypiranganus Ihering \& Ihering, 1907, and Circus spp. where restricted to plots where herbaceous vegetation was taller $(>35 \mathrm{~cm})$.

The second group was formed by species restricted to or more abundant in plots where the mean height of the vegetation was $<20 \mathrm{~cm}$ (Tab. I, Fig. 2). Species in this group included V. chilensis, Geositta cunicularia (Vieillot, 1816), and Anthus furcatus d'Orbigny \& Lafresnaye, 1837. Birds that forage in water or wet pastures were also in this group, including Plegadis chihi (Vieillot, 1817), Bubulcus ibis Leach, 1820, Anthus lutescens Pucheran, 1855, and Anthus correndera Vieillot, 1818. Xolmis dominicanus (Vieillot, 1823) were associated with homogeneous overgrazed pastures.

The last group was comprised by species positively associated with high values of patchiness and woody vegetation, such as Anumbius annumbi (Vieillot, 1817) and Pitangus sulphuratus (Linnaeus, 1766) (Tab. I, Fig. 2). All species in this group were passerines that rely on trees and bushes for perching and nesting and forage on the ground in patches of short grass or in the air.

\section{DISCUSSION}

Of the five variables included in our analyses, the height of the herbaceous vegetation was the main driver of bird species composition in coastal grasslands of southern Brazil. Height of the herbaceous vegetation is one of the most consistent predictors of habitat use by grassland birds (see FISHER \& DAVIS, 2010 and references therein). In structurally simple environments such as grasslands, variation in the height of grasses, sedges, reeds, and forbs plays an overriding role in determining habitat segregation and food specialization among bird species (CODY, 1968; WIENS, 1969, 1974a; FisHER \& DAVIS, 2010). Interspecific competitive exclusion is believed to be the main mechanism explaining occurrence or specialization of birds in grassland vegetation of different heights (CODY, 1968; DAVIS, 2005). Alternatively, adaptive responses to climatic stress or predation risk may explain the segregation of grassland birds in relation to vegetation height (WIENS, 1974b; LUSK et al., 2003; DAVIS, 2005; KeRns et al., 2010).

Species associated with intermediate and tall herbaceous vegetation formed a continuum along the first ordination axis. Among species associated with vegetation of intermediate height, N. maculosa and M. chimango are habitat generalists known to use different kinds of grassland habitats, including overgrazed pastures and agricultural areas (BELTON, 1994; IsACCH \& CARDONI, 2011; AzPIROZ et al., 2012). Anthus hellmayri, on the other hand, appears to be typical of grasslands of intermediate height. Embernagra platensis, S. luteola and S. superciliaris are known to use a broader spectrum of vegetation height in Pampas and Campos grasslands, but, similarly to what we found, tend to be more abundant in medium to tall herbaceous habitats (Ridgely \& Tudor, 1989; Belton, 1994; Azpiroz \& Blake, 2009; IsACCH \& CARDONI, 2011; AzPIROZ et al., 2012).

Circus spp., C. platensis, and E. ypiranganus were restricted to the taller extreme of the height gradient. The latter two are part of a group of 25 bird species, mostly passerines, recorded exclusively in tall grassland habitats in southeastern South America (AzPIROz et al., 2012). Circus spp. were associated with tall herbs both in our study area and in the Argentinean Pampas (IsACCH \& CARDONI, 2011). Harriers prefer to hunt in low flight over denser and taller grassy vegetation, and may take advantage of vegetation cover to surprise prey on the ground (MACWHIRTER \& BildsteIn, 1996). Their short digits and relatively long and slender tarsi probably are adaptations for capturing prey in tall grass and heavy ground cover (EINODER \& RICHARDSON, 2007). Both harriers, however, are not entirely restricted to this extreme of the vegetation-height gradient in southeastern South America (AzPIROz et al., 2012), and 
Tab. I. Abundance (N) and incidence (I) of bird species recorded in 33 plots in coastal grasslands of southern Brazil. The mean height of the herbaceous vegetation $( \pm \mathrm{SD})$, the mean patchiness of herbaceous vegetation $( \pm \mathrm{SD})$, and the mean cover of woody vegetation $( \pm \mathrm{SD})$ in plots where each species was present are given. The percentage of plots containing woody vegetation in relation to the total number of plots where each species occurred is in parenthesis. Global (G) and regional (R) threat status follow IUCN (2012) and BENCKE et al. (2003), respectively (VU, vulnerable; En, endangered). The numeric code indicates species in Fig. 2.

\begin{tabular}{|c|c|c|c|c|c|c|c|}
\hline Taxon & $\mathrm{N}$ & $\mathrm{I}(\%)$ & Height $(\mathrm{cm})$ & Patchiness & Woody vegetation $\left(\mathrm{m}^{2}\right)$ & Threat status & Code \\
\hline \multicolumn{8}{|l|}{ Tinamidae } \\
\hline Nothura maculosa (Temminck, 1815) & 14 & 33 & $29.5 \pm 17.6$ & $0.9 \pm 0.3$ & $0.91 \pm 3.02(9)$ & - & 1 \\
\hline \multicolumn{8}{|l|}{ Ardeidae } \\
\hline Bubulcus ibis Leach, 1820 & 29 & 15 & $12.8 \pm 4.9$ & $0.9 \pm 0.6$ & $6.00 \pm 6.52(50)$ & - & 2 \\
\hline \multicolumn{8}{|l|}{ Threskiornithidae } \\
\hline Plegadis chihi (Vieillot, 1817) & 23 & 9 & $15.2 \pm 5.6$ & $0.9 \pm 0.6$ & $0.00(0)$ & - & 3 \\
\hline Circus cinereus Vieillot, 1816 & 3 & 9 & $54.2 \pm 4.7$ & $0.7 \pm 0.1$ & $0.00(0)$ & $\mathrm{Vu}(\mathrm{R})$ & 4 \\
\hline Circus buffoni (Gmelin, 1788) & 4 & 12 & $51.3 \pm 4.6$ & $0.7 \pm 0.1$ & $0.00(0)$ & - & 5 \\
\hline \multicolumn{8}{|l|}{ Charadriidae } \\
\hline Pluvialis dominica (Statius Muller, 1776) & 48 & 18 & $9.0 \pm 4.4$ & $1.0 \pm 0.7$ & $30.83 \pm 73.10(33)$ & - & 6 \\
\hline Vanellus chilensis (Molina, 1782) & 473 & 94 & $21.3 \pm 16.4$ & $1.0 \pm 0.5$ & $8.39 \pm 32.31(26)$ & - & 7 \\
\hline \multicolumn{8}{|l|}{ Strigidae } \\
\hline \multicolumn{8}{|l|}{ Falconidae } \\
\hline Milvago chimango (Vieillot, 1816) & 25 & 33 & $25.3 \pm 16.1$ & $1.1 \pm 0.4$ & $2.27 \pm 5.18(18)$ & - & 9 \\
\hline \multicolumn{8}{|l|}{ Furnariidae } \\
\hline Geositta cunicularia (Vieillot, 1816) & 7 & 15 & $13.4 \pm 4.3$ & $1.4 \pm 0.5$ & $4.00 \pm 8.94(20)$ & - & 10 \\
\hline Anumbius annumbi (Vieillot, 1817) & 21 & 21 & $14.3 \pm 5.8$ & $1.3 \pm 0.6$ & $36.43 \pm 63.49(100)$ & - & 11 \\
\hline \multicolumn{8}{|l|}{ Tyrannidae } \\
\hline Xolmis dominicanus (Vieillot, 1823) & 5 & 9 & $6.5 \pm 1.4$ & $0.5 \pm 0.0$ & $3.33 \pm 2.89(67)$ & $\mathrm{Vu}(\mathrm{G}, \mathrm{R})$ & 12 \\
\hline Machetornis rixosa (Vieillot, 1819) & 7 & 18 & $15.5 \pm 4.9$ & $1.6 \pm 0.4$ & $39.17 \pm 69.31(83)$ & - & 13 \\
\hline Pitangus sulphuratus (Linnaeus, 1766) & 6 & 15 & $11.5 \pm 4.4$ & $1.5 \pm 0.5$ & $42.00 \pm 77.51(60)$ & - & 14 \\
\hline Tyrannus savana Vieillot, 1808 & 8 & 15 & $14.4 \pm 4.9$ & $1.7 \pm 0.4$ & $41.00 \pm 77.97(60)$ & - & 15 \\
\hline \multicolumn{8}{|l|}{ Troglodytidae } \\
\hline Cistothorus platensis (Latham, 1790) & 10 & 15 & $52.2 \pm 5.7$ & $0.6 \pm 0.1$ & $0.00(0)$ & En $(\mathrm{R})$ & 16 \\
\hline \multicolumn{8}{|l|}{ Motacillidae } \\
\hline Anthus furcatus d'Orbigny \& Lafresnaye, 1837 & 116 & 52 & $12.7 \pm 4.5$ & $1.1 \pm 0.4$ & $2.65 \pm 2.15(18)$ & - & 18 \\
\hline Anthus correndera Vieillot, 1818 & 26 & 18 & $12.7 \pm 5.7$ & $0.9 \pm 0.4$ & $1.67 \pm 4.08(17)$ & - & 19 \\
\hline Anthus hellmayri Hartert, 1909 & 70 & 61 & $31.3 \pm 18.9$ & $0.9 \pm 0.3$ & $1.75 \pm 4.38(15)$ & - & 20 \\
\hline \multicolumn{8}{|l|}{ Thraupidae } \\
\hline Sicalis luteola (Sparrman, 1789) & 278 & 73 & $28.7 \pm 18.1$ & $1.0 \pm 0.5$ & $9.58 \pm 36.62(21)$ & - & 21 \\
\hline Emberizoides ypiranganus Ihering \& Ihering, 1907 & 16 & 24 & $51.1 \pm 7.8$ & $0.7 \pm 0.1$ & $0.00(0)$ & - & 22 \\
\hline Embernagra platensis (Gmelin, 1789) & 46 & 39 & $38.7 \pm 18.9$ & $1.0 \pm 0.5$ & $1.15 \pm 4.16(8)$ & - & 23 \\
\hline \multicolumn{8}{|l|}{ Emberizidae } \\
\hline Ammodramus humeralis (Bosc, 1792) & 4 & 9 & $37.4 \pm 14.5$ & $0.9 \pm 0.3$ & $3.33 \pm 5.77(33)$ & - & 24 \\
\hline \multicolumn{8}{|l|}{ Icteridae } \\
\hline Pseudoleistes virescens (Vieillot, 1819) & 120 & 39 & $17.1 \pm 12.6$ & $1.1 \pm 0.5$ & $4.23 \pm 6.07(38)$ & - & 25 \\
\hline Molothrus bonariensis (Gmelin, 1789) & 22 & 21 & $11.2 \pm 3.8$ & $1.1 \pm 0.6$ & $7.86 \pm 8.59(43)$ & - & 26 \\
\hline Sturnella superciliaris (Bonaparte, 1850) & 78 & 33 & $42.3 \pm 15.7$ & $0.8 \pm 0.2$ & $0.91 \pm 3.02(9)$ & - & 27 \\
\hline
\end{tabular}

can be seen foraging over other habitat types (BELTON, 1994; BENCKE et al., 2003).

Nearly half the species in our study area were associated with short herbaceous vegetation. Among these are birds restricted to short-grass habitats in South America, including V. chilensis, Pluvialis dominica (Statius Muller, 1776), Athene cunicularia (Molina, 1782), G. cunicularia, A. lutescens, and A. furcatus (AzPIroz et al., 2012). Some species recorded in short herbaceous vegetation use a broader spectrum of the vegetation-height gradient in southeastern South America, such as A. correndera and
Molothrus bonariensis (Gmelin, 1789) (AzPIroz et al., 2012). Vanellus chilensis was frequently found in patches of short grasses in plots with predominance of taller herbs, and its large size enabled it to occur in comparatively taller vegetation than other short-grass birds. Xolmis dominicanus and Pseudoleistes virescens (Vieillot, 1819) usually forage in short-grass pastures in southern Brazil, but roost and nest in tall, dense herbaceous vegetation in adjacent marshes (Belton, 1994; Bencke et al., 2003; RAD and ATG, pers. observ.).

Inclusion of species associated with wet habitats 
among short-grass grassland birds can be explained by the fact that the larger expanses of water were found in short grass plots. Furthermore, risk of predation or limitation in prey detection may be higher in water puddles surrounded by tall, dense tussocks than in more open vegetation.

Patchiness of the height of the herbaceous vegetation and cover of woody vegetation contributed to explain the occurrence of invertebrate-eating passerines that rely on woody vegetation for perching, nesting and resting. Both variables tended to reach higher values in plots located in crests of ancient transgressive dune fields, possibly because livestock rest in these areas and trample the vegetation into patches of contrasting height, and also because these features do not flood, enabling the development of cactuses and saplings. Disturbance caused by intermediate to light levels of grazing and trampling increases the structural diversity of the vegetation; this increases invertebrate abundance and diversity, thus benefiting invertebrateeating grassland birds (GiBson et al., 1992; TUCKER, 1992; PERKINS et al., 2000).

Woody vegetation is known to provide nest sites, shade, and food resources for animals in open-vegetation ecosystems and it is an important driver of avian diversity in grasslands (DEAn et al., 1999; Tews et al., 2004). Large clumps of cacti in our study area can reach $15-20 \mathrm{~m}^{2}$ and be nearly $2 \mathrm{~m}$ high, providing shelter and perching sites for birds in grasslands. Nests of $A$. annumbi were commonly found in cacti. We also recorded Furnarius rufus (Gmelin, 1788), Phacellodomus striaticollis (d'Orbigny \& Lafresnaye, 1838), Satrapa icterophrys (Vieillot, 1818), Xolmis irupero (Vieillot, 1823), and Mimus saturninus (Lichtenstein, 1823) in plots with woody vegetation, but due to their scarceness these species were not included in our analyses. This suggests that presence of woody vegetation in grasslands increases bird diversity by adding vertical vegetation strata in an overall horizontal environment, as observed in North American shrublands and grasslands (WIENS, 1974a; Rотн, 1976). Thus, small trees and cacti in our study system may function as "keystone structures" (TEws et al., 2004), enabling the occurrence of a set of species that otherwise would not find adequate habitat in grasslands.

Because tall herbaceous plants in our study area are unpalatable for livestock, management practices are aimed at eliminating these plants by burning, mowing, or trampling by cattle (RAD and ATG, pers. observ.). Consequently, birds restricted to or more abundant in tall herbaceous vegetation are probably negatively affected by habitat degradation resulting from local livestock management practices. Short-grass birds, on the other hand, likely benefit from local livestock ranching.

Xolmis dominicanus is the only threatened species associated with short-grass pastures in our study area. This bird is a perch-to-ground forager that relies on slightly elevated perches to scan invertebrate prey on the ground (FitzPATRICK, 1980; BencKe et al., 2003). Thus, detection and capture of small prey on the ground may be easier in short-grass. However, since this species nests and roosts in tall, dense herbaceous vegetation in marshes, it is also dependent on the availability of such type of habitat to survive (BENCKE et al., 2003).

Regionally threatened species in our study area are predominantly tall-grass birds. Cistothorus platensis fulfills its entire life cycle in tall and dense herbaceous vegetation, while Circus cinereus Vieillot, 1816 prefers to hunt in tall-grass and uses stands of dense herbaceous plants in marshes for nesting and roosting (BENCKE et al., 2003; RAD and ATG, pers. observ.). As a group, tall-grass species are particularly vulnerable to habitat degradation resulting from livestock ranching (AzPIROz et al., 2012). In fact, most regionally or globally threatened grassland birds in the Campos region are restricted to tall herbaceous vegetation, or depend on such formations during some phase of their life cycles (BENCKe et al., 2003; AzPIRoz et al., 2012). Persistence of tall-grass species in our study area is related to the occurrence of shallow depressions in the terrain where eradication of clumps of grasses and reeds is difficult and relict patches endure.

Conciliating rangeland management and grassland bird conservation has proven to be challenging because of the different habitat requirements of species, physical characteristics of grasslands, and the type of grazing regime practiced by ranchers (COPPEDGe et al., 2008; Derner et al., 2009). In coastal grasslands of southern Brazil, a continuous grazing regime is used, and local management techniques result in the elimination or reduction of tallherb stands. Therefore, we advocate that an among-pasture scale heterogeneity approach would be more effective in enabling the development of a mosaic of distinct habitat patches in the landscape capable of fulfilling the habitat needs of multiple species (DERNER et al., 2009).

In conclusion, we demonstrated that the height of the herbaceous vegetation, the presence of patches of variable vegetation height, and the cover of cacti and saplings determine the occurrence of three subsets of bird species in southern Brazilian grasslands. Current management practices result in habitat degradation via the elimination or reduction of unpalatable, tall grassland plants. While on the one hand this benefits short-grass birds and provides foraging habitat for one globally threatened species, on the other tall grassland birds are negatively affected, especially specialists of tall herbaceous plants, including regionally threatened species. Although livestock ranching has been viewed as a promoter of diversity through the creation of distinct patches of vegetation height in grasslands, maintenance of stands of tall herbaceous plants large enough to sustain populations of habitat specialists is needed to ensure the survival of species dependent on tall grassland formations.

Acknowledgments. We thank G. Ritchison and five anonymous reviewers for their valuable insights to the manuscript. G. A. Bencke, L. Bugoni, S. M. Hartz, and S. C. Müller reviewed a previous version of this work. N. M. Gianuca assisted with logistics during fieldwork. R. A. Dias was funded by the Universidade Católica de Pelotas. 


\section{REFERENCES}

Allred, B. W.; Fuhlendorf, S. D.; Engle, D. M. \& Elmore, R. D. 2011. Ungulate preference for burned patches reveals strength of firegrazing interaction. Ecology and Evolution 1:132-144.

Atkinson, P. W.; Fuller, R. A.; Gillings, S. \& Vickery, J. A. 2006. Counting birds on farmland habitats in winter. Bird Study 53:303309.

Azpiroz, A. B. \& Blake, J. G. 2009. Avian assemblages in altered and natural grasslands in the Northern Campos of Uruguay. Condor 111:21-35.

Azpiroz, A. B.; Isacch, J. P.; Dias, R. A.; Di Giacomo, A. S.; Fontana, C. S. \& Palarea, C. M. 2012. Ecology and conservation of grassland birds in southeastern South America: a review. Journal of Field Ornithology 83:217-246.

BÁLDI, A. \& BATÁRY, P. 2011. Spatial heterogeneity and farmland birds: different perspectives in Western and Eastern Europe. Ibis 153:875876.

Belton, W. 1994. Aves do Rio Grande do Sul, distribuição e biologia. São Leopoldo, Unisinos. 584p.

Bencke, G. A.; Fontana, C. S.; Dias, R. A.; Maurício, G. N. \& MählerJR, J. K. F. 2003. Aves. In: Fontana, C. S.; Bencke, G. A. \& ReIs, R. E. eds. Livro vermelho da fauna ameaçada de extinção no Rio Grande do Sul. Porto Alegre, Edipucrs. p.189-479.

BibBy, C. J.; Burgess, N. D. \& Hill, D. A. 1992. Bird census techniques. London, Academic Press. 302p.

Ceballos, G.; Pacheco, J. \& List, R. 1999. Influence of prairie dogs (Cynomys ludovicianus) on habitat heterogeneity and mammalian diversity in Mexico. Journal of Arid Environments 41:161-172.

Cody, M. L. 1968. On the methods of resource division in grassland bird communities. American Naturalist 102:107-147.

Comparatore, V. M.; Martínez, M. M.; Vasallo, A. I.; Barg, O. M. \& IsACCH, J. P. 1996. Abundancia y relaciones con el hábitat de aves y mamíferos en pastizales de Paspalum quadrifarium (paja colorada) manejados con fuego (Provincia de Buenos Aires, Argentina). Interciencia 21:228-237.

Coppedge, B. R.; Fuhlendorf, S. D.; Harrell, W. C. \& Engle, D. M. 2008. Avian community response to vegetation and structural features in grasslands managed with fire and grazing. Biological Conservation 141:1196-1203.

DAVIS, S. K. 2005. Nest-site selection patterns and the influence of vegetation on nest survival of mixed-grass prairie passerines. Condor 107:605-616.

Dean, W. R. J.; Mitton, S. J. \& Jeltsch, F. 1999. Large trees, fertile islands, and birds in arid savanna. Journal of Arid Environments 41:61-78.

Derner, J. D.; Lauenroth, W. K.; Stapp, P. \& Augustine, D. J. 2009. Livestock as ecosystem engineers for grassland bird habitat in the Western Great Plains of North America. Rangeland Ecology \& Management 62:111-118.

Develey, P. F.; Setubal, R. B.; Dias, R. A. \& Bencke, G. A. 2008. Conservação das aves e da biodiversidade no bioma Pampa aliada a sistemas de produção animal. Revista Brasileira de Ornitologia 16:308-315.

DienI, J. C. \& Jones, S. L. 2002. A field test of the area search method for measuring breeding bird populations. Journal of Field Ornithology 73:253-257.

Einoder, L. D. \& Richardson, A. M. M. 2007. Aspects of the hindlimb morphology of some Australian birds of prey: A comparative and quantitative study. The Auk 124:773-788.

Fisher, R. J. \& DAVIS, S. K. 2010. From Wiens to Robel: a review of grassland-bird habitat selection. Journal of Wildlife Management 74:265-273.

FitzPatrick, J. W. 1980. Foraging behavior of Neotropical tyrant flycatchers. Condor 82:43-57.

Fuhlendorf, S. D.; Engle, D. M.; Kerby, J. \& Hamilton, R. 2009. Pyric herbivory: Rewilding landscapes through the recoupling of fire and grazing. Conservation Biology 23:588-598.

GRESSLER, D. T. 2008. Effects of habitat fragmentation on grassland bird communities in a private farmland in the Pampa biome. Revista Brasileira de Ornitologia 16:316-322.
Gibson, C. W. D.; Hambler, C. \& Brown, V. K. B. 1992. Changes in spider (Araneae) assemblages in relation to succession and grazing management. Journal of Applied Ecology 29:132-142.

Henwood, W. D. 2010. Toward a strategy for the conservation and protection of the world's temperate grasslands. Great Plains Research 20:121-134.

IBGE - Instituto Brasileiro de Geografia e Estatística. 1986. Folha SH.22 Porto Alegre e parte das Folhas SH. 21 Uruguaiana e SI.22 Lagoa Mirim: geologia, geomorfologia, pedologia, vegetação, uso potencial da terra. (Levantamento de Recursos Naturais, 33). Rio de Janeiro, IBGE. 791p.

IUCN - InTERNATIONAL UNION FOR CONSERVATION OF NATURE. 2012. IUCN Red List of Threatened Species. Version 2012.2. Available at $<\mathrm{http}: / /$ www.iucnredlist.org>. Accessed on 01 June 2013.

IsACCH, J. P. \& MartíneZ, M. M. 2001. Estacionalidad y relaciones con la estructura del hábitat de la comunidad de aves de pastizales de paja colorada (Paspalum quadrifarium) manejados con fuego en la provincia de Buenos Aires, Argentina. Ornitología Neotropical 12:345-354.

2003. Habitat use by nonbreeding shorebirds in flooding pampa grasslands of Argentina. Waterbirds 26:494-500.

IsACCH, J. P. \& CARDONI, D. A. 2011. Different grazing strategies are necessary to conserve endangered grassland birds in short and tall salty grasslands of the flooding Pampas. Condor 113:724-734.

Isacch, J. P.; Maceira, N. O.; Bó, M. S.; Demaría, M. R. \& Peluc, S. 2005. Bird-habitat relationship in semiarid natural grasslands and exotic pastures in the West pampas of Argentina. Journal of Arid Environments 62:267-283.

Kerns, C. K.; Ryan, M. R.; Murphy, R. K.; Thompson, F. R., III \& Rubin, C. S. 2010. Factors affecting songbird nest survival in northern mixed-grass prairie. Journal of Wildlife Management 74:257-264.

LegendRe, P. \& LegendRE, L. 1998. Numerical ecology. Amsterdam, Elsevier. 1006p.

LEPŠ, J. \& ŠMILAUER, P. 2003. Multivariate analysis of ecological data using CANOCO. Cambridge, Cambridge University Press. 284p.

Lusk, J. J.; Wells, K. S.; Guthery, F. S. \& Fuhlendorf, S. D. 2003. Lark Sparrow (Chondestes grammacus) nest-site selection and success in a mixed-grass prairie. Auk 120:120-129.

MAcWhirTer, R. B. \& Bildstein, K. L. 1996. Northern Harrier (Circus cyaneus). In: Poole, A. \& Gill, F. eds. The Birds of North America. (no. 210). Philadelphia \& Washington, D.C., The Academy of Natural Sciences \& The American Ornithologists' Union. p.1-32.

Maurício, G. N.; Bencke, G. A.; Repenning, M.; Machado, D. B.; Dias, R. A. \& Bugoni, L. 2013. Review of the breeding status of birds in Rio Grande do Sul, Brazil. Iheringia, Série Zoologia 103(2):163-184.

McCoy, T. D.; Ryan, M. R.; Burger, L. W., JR. \& KurZejeski, E. W. 2001. Grassland bird conservation: $\mathrm{CP} 1$ vs. CP2 plantings in Conservation Reserve Program Fields in Missouri. American Midland Naturalist 145:1-17.

Perkins, A. J.; Whittingham, M. J.; Bradbury, R. B.; Wilson, J. D.; MorRis, A. J. \& BARNETT, P. R. 2000. Habitat characteristics affecting use of lowland agricultural grassland by birds in winter. Biological Conservation 95:279-294.

Ralph, C. J.; Geupel, G. R.; Pyle, P.; Martin, T. E. \& DeSante, D. F. 1993. Handbook of field methods for monitoring landbirds. (Technical Report PSW-GTR-144). Albany, U.S. Department of Agriculture, Forest Service, Pacific Southwest Research Station. 41p.

ReEse, K. P. \& RatTi, J. T. 1988. Edge effect: a concept under scrutiny. Transactions of the North American Wildlife and Natural Resources Conference 53:127-136.

Remsen, J. V., Jr.; Cadena, C. D.; Jaramillo, A.; Nores, M.; Pacheco, J. F.; Pérez-Emán, J.; Robiins, M. B.; Stiles, F. G.; Stotz, D. F. \& ZimmeR, K. J. 2013. A classification of the bird species of South America. American Ornithologists' Union. Available at $<$ www.museum.lsu. edu/ Remsen/SACCBaseline.html>. Accessed on 01 June 2013.

Ridgely, R. S. \& Tudor, G. 1989. The birds of South America. Vol. I. The oscine passerines. Austin, University of Texas Press. 596p.

RoBerTs, J. P. \& SCHNELL, G. D. 2006. Comparison of survey methods for wintering grassland birds. Journal of Field Ornithology 77:46-60. 
Rотн, R. R. 1976. Spatial heterogeneity and bird species diversity. Ecology 57:773-782.

TER BRAaK, C. J. F. 1986. Canonical Correspondence Analysis: a new eigenvector technique for multivariate direct gradient analysis. Ecology 67:1167-1179.

ter BraAk, C. J. F. \& ŠMilauer, P. 2002. CANOCO reference manual and CanoDraw for Windows user's guide. Software for canonical community ordination (version 4.5). Ithaca, Biometrics. 500p.

Tews, J.; Brose, U.; Grimm, V.; Tielbörger, K.; Wichmann, M. C.; Schwager, M. \& Jeltsch, F. 2004. Animal species diversity driven by habitat heterogeneity/diversity: the importance of keystone structures. Journal of Biogeography 31:79-92.
Tucker, G. M. 1992. Effects of agricultural practice on field use by invertebrate-feeding birds in winter. Journal of Applied Ecology 29:779-790.

VICKERY, P. D. \& HERKERT, J. R. 2001. Recent advances in grassland bird research: where do we go from here? Auk 118:11-15.

WiENs, J. A. 1969. An approach to the study of ecological relationships among grassland birds. Ornithological Monographs 8:1-93.

1974a. Habitat heterogeneity and avian community structure in North American grasslands. American Midland Naturalist 91:195-213.

1974b. Climatic instability and the "ecological saturation" of bird communities in North American grasslands. Condor 76:385-400. 